\title{
'I DO' BELONG TO YOU: DEBATING THE VULNERABILITY OF FILIPINO MAIL-ORDER BRIDES IN CANADA
}

by

Kathryn Jane Hodges, BA, University of Alberta, 2009

A Major Research Paper

presented to Ryerson University

in partial fulfillment of the requirements for the degree of

\author{
Master of Arts \\ in the Program of \\ Immigration and Settlement Studies
}

Toronto, Ontario, Canada, 2010

(C) Kathryn Hodges 2010 


\section{Author's Declaration}

I hereby declare that I am the sole author of this major research paper.

I authorize Ryerson University to lend this paper to other institutions or individuals for the purpose of scholarly research.

I further authorize Ryerson University to reproduce this paper by photocopying or by other means, in total or in part, at the request of other institutions or individuals for the purpose of scholarly research. 


\title{
'I DO' BELONG TO YOU: QUESTIONING THE VULNERABILITY OF FILIPINO MAIL-ORDER BRIDES IN CANADA
}

\author{
Kathryn Jane Hodges \\ Master of Arts, 2010 \\ Immigration and Settlement Studies \\ Ryerson University
}

\begin{abstract}
This qualitative essay examines to what extent mail-order brides are a vulnerable population, concentrating on Filipino mail-order brides in Canada. The literature on mail-order brides has generally been polarized between two positions, one that tries to victimize all mail-order brides and one that tries to presume that all mail-order brides are in control of their own destinies. This paper aims to assess these polarized positions on the basis of empirical information provided in the literature and two interviews done with representatives from organizations that work with the Filipino community in Canada.
\end{abstract}

\section{Key words:}

An article on Filipino mail-order brides in Canada, used the key words: mail-order bride, Philippines, Canada, vulnerability, dependency 


\section{Table of Contents}

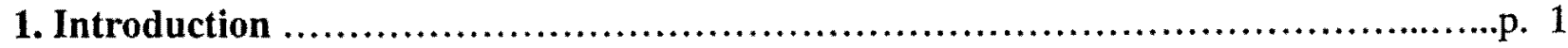

1.1 The Philippines: A Leading Exporter in Mail-Order Brides .......................p. 5

1.2 Outlining the Debate Surrounding Mail-Order Brides...............................p. 8

2. Methodology .......................................................................... 11

3. Mail-Order Brides: Review of the Literature......................................... 14

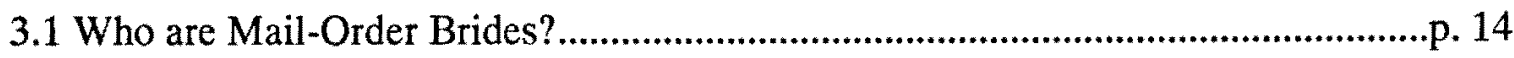

3.1.1 Defining a Mail-Order Bride ........................................p. 14

3.1.2 Characterizing the Mail-Order Bride....................................p. 17

3.2 Why Women Become Mail-Order Brides.....................................p. 18

3.2.1 Global Economic Inequality ........................................p. 18

3.3 What Vulnerabilities Do Mail-Order Brides Face?..................................................... 20

3.3.1 Immigrating to Canada as a Mail-Order Bride..........................p. 20

3.3.2 Economic Vulnerabilities Faced by Mail-Order Brides...................p. 22

3.3.3 Social Vulnerabilities Faced by Mail-Order Brides.......................p. 25

3.3.4 The Human Trafficking Discourse and Mail-Order Brides...............p. 26

3.4 What is Being Done to Help Mail-Order Brides?........................................................p. 28

3.4.1 Laws Pertaining to Mail-Order Brides................................p. 28

4. Interviews with Organization Representatives...................................p. 33

4.1 Interview with Eve.....................................................p. 33

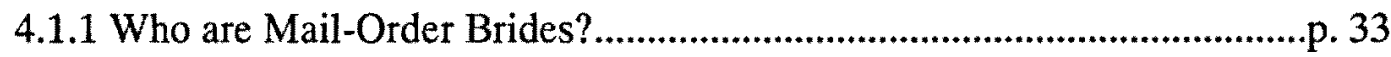

4.1.2 Why do Women Become Mail-Order Brides?...........................................p. 34

4.1.3. Vulnerabilities Faced by Mail-Order Brides?........................................p. 34

4.1.4. Positive Experiences.................................................... 37

4.2 Interview with Lydia......................................................p. 38

4.2.1 Who are Mail-Order Brides? .......................................................................p. 38

4.2.2 Why do Women Become Mail-Order Brides?.........................................p. 39

4.2.3 Vulnerabilities Faced by Mail-Order Brides.........................p. 40

4.2.4 Positive Experiences............................................p. 43

4.3 Comparing and Contrasting Interviews to Mail-Order Bride Literature......p. 43 5. What is to be Done?: Suggestions for Providing Protection to Mail-Order Brides in Canada. p. 47

6. Conclusion

7. References. 
"People in the Philippines are commodities"1

\section{Introduction}

A woman arrives in Canada after living her whole life in the same city of the Philippines. She may be greeted by her new husband who has investigated and found stores that sell Filipino products. He may have looked for Filipino organizations that she can get involved in to find other women that will understand her homesickness in order to ease the lonely hours she would otherwise spend at home while her husband is at work. He may show her how to take the bus to the organization, his favorite restaurant for take-out food if they are too busy to cook dinner, and proudly introduce his new wife to his family and friends.

Then again, he may not. Alternatively, a woman may arrive in a new country after living her whole life in the same city to find a husband who is upset that her plane came in late. He may take her to his run-down home, where his three young children are waiting to be fed and bathed before being put to bed. Once they are all asleep, he may install himself in front of the television to watch football, muttering thanks that there is someone to take care of the kids now so he will no longer have to miss the beginning of the games.

Worse, a woman may arrive in a new country after living her whole life in the same city to find a husband who picks her up at the airport and tells her she was brought over to work for him, nothing more. While she is still settling in, her husband may get angry at her for not knowing how to say certain words in English or being unaware of some of the customs he is used to, in some cases resorting to violence to express his displeasure. Feeling homesick, she may ask to use his computer so she can email her friends and family back home and he may tell her she is

\footnotetext{
${ }^{1}$ A quote from my interview with Lydia, a community worker with the Filipino community.
} 
not allowed. He is the only person that she should be in contact with, and he gets to make all the rules because he was the one who paid for her to come over to Canada after all.

These are all hypothetical stories that show the varied experiences mail-order brides may have upon migrating to be with their husbands, but they are grounded in truth. The three stories do not discuss the differences present between mail-order brides on an individual level, such as previous education or whether they are responsible for helping to support their families back home. These stories do, however, highlight the potential vulnerability mail-order brides may face upon migrating to Canada. Literary sources highlight the fact that these women encounter hardship through no fault of their own and may be victims because of their dependence on their husbands to stay in the country and for financial support. The question of the vulnerability of mail-order brides has been approached differently by different scholars, but each answer is given to the population of mail order brides as a whole, and fails to take into consideration the extreme variety of individual experiences.

Perspectives on mail-order brides are polarized. Majority of scholars'see mail-order brides as either a vulnerable population collectively or as individuals practicing choice and agency. Choice and agency act as one position because these women are actively choosing to move. They may be seen as vulnerable because they may not have much choice in the matter if they are moving because of abject poverty, suggesting that there may be no real choice. Rather than categorically accepting one or the other perspective, I argue that both vulnerability, on the one hand, and choice and agency, on the other, are possibilities and that they often co-exist in the individual experiences of mail-order brides. It is not that women choosing to become mail-order brides are ignorant of vulnerabilities that face them; but they may still feel pressured to make that "choice" in the absence of other opportunities. There is freedom of choice in becoming a mail- 
order bride but there may also be a lack of real choice to do anything else. There are surely vulnerabilities that do face them, but there is also the possibility of different opportunities in life and happiness.

Unlike most scholars who have written on the subject, I am not comfortable claiming that there is only one answer or one possible outcome for mail-order brides. This is a diverse group of women that have individual experiences before and after immigration. Mail-order brides are not universally victims that need rescuing. However, because of the vulnerability they may potentially experience, I believe that there should be policies and laws in place to ensure the safety and equality of status in society and family of all of these women. My contribution to this field will be to give a more nuanced approach and highlight the diversity of experiences in a group that is often homogenized. There is a need to assess the polarized positions taken by scholars on the subject of mail-order brides. Through my research, I was deliberate about emphasizing individuality among mail-order brides instead of limiting them as a group to one narrative.

This paper will start by contextualizing the history of mail-order brides in North America, and then focus on the case of Filipino mail-order brides. Even when narrowing the focus down to Filipino mail-order brides there are still significant differences among women entering Canada as mail-order brides, and one must question whether mail-order brides should be deemed a vulnerable population. To answer this question, I have structured this paper to answer four subquestions: who is a mail-order bride, why do women become mail-order brides, what vulnerabilities are faced by mail-order brides, and what is Canada's responsibility towards these women? In addressing these questions, the paper mostly critically reviews the existing academic literature on the topic. In addition, the paper is informed by findings based on two interviews 
with organizational representatives who have worked with Filipino mail-order brides. I have kept the literature review and interview findings separate but have followed the same organizational headings in both sections to allow for comparison. I conclude the paper by discussing recommendations for protecting mail-order brides within Canada.

In my interviews, there was complete agreement that women decided to become mailorder brides out of economic necessity. Despite this common thread among mail-order brides, their lives before becoming mail-order brides and their experiences as mail-order brides may have relatively little in common. Because of these differences, it is difficult to ban or condemn the practice of becoming a mail-order bride, but the possibility of extreme vulnerability suggests that some regulation would be in everyone's best interest.

The migration of mail-order brides to North America is not a new trend. The first mailorder marriages in the North American context, similar to the current phenomenon of mail-order brides, were "picture brides," a system popular in the early 1900 s (Perez, 215, 2003). In the late $19^{\text {th }}$ and early $20^{\text {th }}$ century, because Asian immigrants in the United States of America were not allowed to marry white women, pictures of women that were looking to marry and willing to move to North America would be circulated around Asian communities in America. ${ }^{2}$ This system, a rather slow one in comparison to the high speed and interactive alternatives available today, provided the same service of allowing two individuals with no personal or family connections who lived in different places to become married.

\footnotetext{
${ }^{2}$ As I have not been able to find conclusive evidence on whether this did or did not happen in Canada, it would be my opinion that if it did happen in Canada it was rather uncommon. Because of the Chinese Head Tax imposed on Chinese immigrants, it was very costly to bring a wife or a bride into the country. This resulted in a high imbalanced male/female ratio in the Chinese Canadian Community. The 1911 Canadian census showed that there were 2,790 Chinese men for every 100 females (Boyd and Vickers, 2000, 5).
} 
In this essay, I will be focusing exclusively on Filipino mail-order brides. Filipino mailorder brides make an interesting case study, both because of the centrality of remittances to the Philippines economy and because of the anti-mail-order bride legislation this country has introduced. The Philippines relies very heavily on remittances from abroad to sustain its economy. Many families are dependent on these remittances for their everyday lives and there are expectations that family members will go abroad as a way of helping their family at home. Becoming a mail-order bride is a possible avenue of leaving the country that does not require a specific type of education or related work experience. Despite the government of the Philippines actively encouraging citizens to work abroad, legislation has made mail-order bride agencies illegal. Therefore, on the one hand, the country bans this form of migration, yet on the other hand, it continues to actively encourage the act of sending money from abroad. These two policies seem to send mixed signals.

\subsection{The Philippines: A Leading Exporter in Mail-Order Brides}

While in the past the majority of picture brides were from Japan and Korea and were married to Japanese and Korean men living in North America, it is currently the trend that white men search for foreign brides; and the Philippines is the most popular source for Asian mailorder brides (Perez, 217, 2003). The Philippines have been touted by Mila Glodava and Richard Onizuka as having "a working familiarity of American culture", with "widespread schooling in English, a dash of colonial mentality, just enough prosperity to elicit a craving for more, Catholicism, and horrendous unemployment," making the country ideal candidate for mail-order brides $(1994,55)$. To understand why the Philippines is seen this way, one must review the recent history of the Philippines. Colonized by the Spanish in the $16^{\text {th }}$ century, there was great pressure to convert to Catholicism (Nadeau, 2008, 22), making the Philippines one of the two 
countries in Asia with a predominantly Roman Catholic population. ${ }^{3}$ This would appeal to many men in North America, who are predominantly Christian, who hope for similar values and celebrating the same religious holidays with their wives. Following Spanish colonialism, the Philippines were then colonized by the United States of America. As early as 1904, under American imperialism, English became the language of instruction at schools, with American history and culture being taught to all students (Nadeau, 2008, 51). This is a factor in why many Filipinos can speak English. Because of these reasons, it is assumed that Filipinos would make an easier transition to North American society. There is also a willingness to leave the country because of the harsh economic conditions. In the 1960s, the Philippines were seen as a success story in democratic reform (Nadeau, 208, 81). Comfortably middle-class and largely literate, its population seemed to have hopes for a bright economic future. But, after a brutal dictatorship from 1965-1986, rising foreign debt and corruption, the once shiny Philippines was in a sorry state. Economics has been a major motivating factor for women in the Philippines interested in becoming mail-order brides.

The Philippines is a country whose economy is highly dependent on remittances. It is only through transnational space that the Philippine economy stays afloat (Tolentino, 1996, 49). To deal with acute unemployment and poverty within the country, the state actively encourages its citizens to live abroad and to send money back home through the Labour Export Policy, known as the LEP (Alcuitas-Imperial et al., 2000, 11). As Filipino women are often the most likely to be unemployed or in poverty in the Philippines and they are more reliable to send remittances to help provide for their families, they are the logical choice to be encouraged for immigration abroad (Alcuitas-Imperial et al., 2000, 12). With $10 \%$ of their population abroad

\footnotetext{
${ }^{3}$ The other predominantly Catholic Asian country is East Timor.
} 
(Alcuitas-Imperial et al., 2000,10) in 2006, 12.6\% of the Philippines GDP was based on remittances (Carroll, 2007, 2). Because women are far more likely to go abroad and send their regular remittances, some families state, "(g)ive us daughters, they are a hundred times better than sons" (Glodava \& Onizuka, 1994, 93). These women are "hailed as heroines because they become mail-order brides to support their families economically and they represent an opportunity to secure a better future for their relatives" (Belleau, 2003, 96).

There are a number of factors that play into the mail-order bride phenomenon being popular in the Philippines. In addition to unemployment, underemployment and high levels of poverty that add to the economic desperation of individual women, there is increased access to communication overseas with widespread internet. Women also encounter encouragement to go abroad from both the state and family. Furthermore, there are (unrealistic) expectations of 'American' men being better husbands. Since the Philippine-American War of 1899-1902, Filipinas have viewed American men (synonymous for all white men) and America (synonymous for the developed Western world) as superior to what the Philippines and Filipino men can offer to their women (del Rosario, 2008, 85). These factors all contribute to the high number of mail-order brides from the Philippines.

The Filipino women are in high demand as spouses internationally. This is in part because of the image left by the American military based in the Philippines of Filipina "hospitality girls" who are fantasized to do whatever possible to please her husband (Tolentino, 1996, 51, 56). Filipino women are depicted as passive and traditional in comparison to the Western, liberated, women and attractive to men wanting a wife that will stay at home and look after his every need (Tolentino, 1996, 71). Already known to be good at domestic work, these women are portrayed on mail-order bride, or pen pal, websites as having "good old fashioned 
values" (Perez, 2003, 221), and being " selfless, loving, family-oriented, smiling, nonmaterialistic, feminine, and unspoiled" (D'Aoust, 2009, 22). The men that select these women to be their brides often view Western women as too liberated and are actively looking for a passive and submissive wife (Tolentino, 1996, 71). The "ideas about Asia and about the West underlie men's and women's motivations to meet a foreign partner" (Constable, 2003, 216). Both genders believe that they are choosing someone who will suit their needs better than someone in their own country. Misconceptions on both sides are not necessarily accidental, but may be perpetuated through the mail-order bride websites which tell both parties what they want to hear.

\subsection{Outlining the Debate Surrounding Mail-Order Brides}

The debate about mail-order brides among scholars is similar to the debate among feminists about sex trade workers: Are they desperate victims in need of protection or are they bold and brave women practicing choice agency (D'Aoust, 2009, 3)? One side of the debate presents the mail-order bride as extremely vulnerable. In this perspective, the mail-order bride relationships are viewed as a relationship of slavery (see Perez, 2003 and Vergara, 2000), as something that should not be tolerated. This position is based on the idea that men "buying" women for marriage results in a subordinate position for women in general and represents a patriarchal dominance where men may have the opportunity to own and control women completely. The evidence for this position comes from the many abusive relationships that have emerged in mail-order marriages, in the most extreme cases, resulting in death (Perez, 2003, 232). Because of the violence experienced by some mail-order brides, it is not surprising that some, including the Filipino government, think that banning the mail-order bride trade completely is the best method of protecting these women. 
The opposing side of the debate on mail-order brides emphasizes agency and choice. This position would suggest that the women becoming mail-order brides are not ignorant but are making "informed, logical decisions" (Constable, 2003, 6). Interfering with their choice to move away may perpetuate a history of women being told what they are and are not allowed to do, denying them the right to choose the course of their lives. According to this position, portraying all women that become mail-order brides as vulnerable and childlike because of their supposed lack of understanding of the dangers of their decisions is degrading.

Authors emphasizing agency and choice believe that women have the ability to choose this path. They are aware that domestic abuse is a possibility (Constable, 2003, 9-10), but they argue that this is a possibility for all marriages. This side would argue that the mail-order brides are taking control of their own destiny and that they are willingly choosing to move away.

Opposing this view, many would question what type of choice the mail-order brides have coming from developing countries. They may argue that becoming a mail-order bride is always a last resort. They suggest therefore that women in these relationships are in need of protection and care, not because of their lack of intelligence, but because the lack of alternatives to poverty make them willingness to make the marriage work at all costs and therefore create conditions of vulnerability.

Part of the debate surrounding mail-order brides is why women decide to become mailorder brides. If it is because of a lack of other options, then it is understandable that many of these women would not report abuse even if they knew how to because of fear of deportation. A critical opinion of the above statement would be that if a woman became a mail-order bride for reasons other than economic necessity, there is no reason to view her situation as different from 
any other bride within the developed countries as she would be more likely to be able to leave her husband if need be. Scholars ignore that the situation for each mail-order bride is different. There cannot be one analysis in which all mail-order brides are classified as vulnerable nor as secure. Each situation must be examined separately to decide whether the woman involved is a victim of desperate measures, or if she is a mail-order bride because of her desire to find "love, romance or compatibility" (Constable, 3, 2006). 


\section{Methodology}

To obtain the necessary data for this study, I have relied heavily on the existing literature relating to mail-order brides and interviewed two representatives from organizations. These representatives were very knowledgeable on the topic both through their knowledge of the Philippines and of the Filipino community as well as the individual contacts they have had with Filipino mail-order brides. I have compared the information from my interviews with the generally polarized opinions expressed by scholars to show that within the category of mailorder brides there is a vast amount of variation and that this is not one homogeneous population. Instead of having tidy conclusions, either that all mail-order brides are victims of human trafficking or that no mail-order brides are victims of human trafficking, I have been interested in investigating the middle-ground that has generally been neglected in the literature thus far.

I chose to use qualitative research because I am interested in learning and hearing about individual experiences of the participants. Using the social constructivism paradigm which believes that individuals seek to understand the world they live in and that because of different experiences individuals place subjective meanings on different things and experiences (Creswell, $2009,8)$, I recognize that even though there are some similarities between the mail-order brides, ultimately every participant is an individual whose history and life experiences have shaped how they experience and view their lives. It was my goal to accurately represent those that I interviewed and to allow for a holistic approach where individual experiences were valued rather than creating a narrow analysis which assumed homogeneity of experiences among all mailorder brides.

I had difficulty finding mail-order brides who were willing to be interviewed for this study. Unlike many other groups of immigrants who would join together on the basis of 
common experiences to form a support group, mail-order brides often do not publicly identify the reasons for and the nature of their migration. To locate potential participants, I contacted different Filipino organizations to see if they had been in touch with mail-order brides who may have been willing to be participants. These agencies were in touch with some mail-order brides, but these women were not interested in participating for a variety of reasons. There were issues of confidentiality and fears that their arrival in Canada as mail-order brides would be exposed to their community. In addition to the stigma attached to the label of mail-order bride, it is possible that the inevitably sensitive and personal nature of an interview on this topic discouraged potential participants from volunteering to be interviewed. After trying to contact individuals and not being successful, and being wary of the ethical issues of pursuing a population that was not very willing to participate, I instead interviewed two different organizational representatives that have been involved in settlement services in immigrant Filipino communities as an alternative resource.

These representatives were not only very knowledgeable about the topic, they were also sensitive to the kind of problems Filipino immigrants in general and mail-order brides in particular faced in Canada. Although I regret missing the opportunity to hear stories first-hand from those who have been mail-order brides, this alternative source for information proved to be quite useful as I was able to hear about overall trends as well as individual stories about women. There was also a great degree of openness in these interviews because it was easier for organizational representatives to talk about what they had observed than it would have been if they were talking about their own personal experiences. Of course, as these were not accounts from the women that lived through these experiences themselves, I am aware (as I am sure the 
representatives were also aware) that they may not be complete and precise at the same level as first-hand experiences.

To best allow for the participants to share what they had observed through their work with mail-order brides, I followed a narrative research strategy where participants were asked open ended questions that allowed for personal interpretation and encouraged stories about individuals to emerge based on what the participants felt was important and relevant based on their experiences (Creswell, 2009, 13). It was my hope that this approach would allow the participants to share stories that they felt were most relevant. This enabled me as the researcher to understand what the participants defined as the main issues that needed to be discussed.

Ideally, the research would have best benefited from a mixed methods approach that would combine qualitative and quantitative research. Quantitatively, it would have been beneficial to see how many mail-order brides are in Canada currently; rates of emotional and physical abuse experienced by mail-order brides; rates of employment; and whether they had ever attempted to enter the country via different means. Because Canada does not keep track of any of this information, I have not been able to use this kind of quantitative information for my study. 


\section{Mail-Order Brides: Review of the Literature}

The academic literature on mail-order brides is polarized between two equally one-sided perspectives. While one part of the literature approaches mail-order brides as victims of human trafficking, the other part tends to celebrate them for taking control of their own lives and practicing individual agency. The debate on mail-order brides is ongoing, most likely because there is no one answer that can conclusively support and prove the position of either side of the argument. My review of the literature will be organized to address for main sub-questions: who are mail-order brides; why women become mail-order brides; what vulnerabilities mail-order brides may face; and what protection is provided for these women.

\subsection{Who are Mail-Order Brides?}

\subsubsection{Defining a Mail-Order Bride}

Defining a mail-order bride is an issue of contention among scholars. Mila Glodava and Richard Onizuka provide a broad definition of mail-order brides claiming that it is "a catch-all phrase for women who find their spouses through the mail" $(1994,2)$. While this definition is not wrong it is too general as it includes all marriages that happen from an introduction online, regardless of the nationality or the location of the parties. In terms of the focus of my study, a more precise definition for my purposes would be that of Catherine Baillie Abidi and Susan M. Brigham who define a mail-order bride marriage as one involving "a formal transaction between a man (usually from a developed country) and a woman (from a developing country) brokered by an agency via catalogue or internet" $(2008,22)$. The Abidi and Brigham definition insightfully shows that mail-order brides are not without a male counterpart. While both man and woman are involved in a mail-order relationship, it is only the wife who has the stigma of a title 
associated with her. In my major research paper, I focus on relationships where the husband comes from a developed nation and has met his bride over the internet or through a dating agency. The mail-order brides in my essay are women coming from a developing country to a developed country to marry someone who they have met through an agency or internet but have no mutual acquaintances with through family or friends. This is meant to exclude any type of arranged marriage; it is two individuals with no social connections between them. While recognizing that the term mail-order bride may make some scholars and women themselves uneasy because of the negative connotations associated with the term (such as the woman being bought or suggesting that the couple does not love each other) I will be using it for this essay because it is more precise in nature for describing the group of women I am investigating. It is also the most common term in popular use and in the academic literature.

The definition of a mail-order marriage that I use underlines the importance of the place of birth, and the absence of a support system (outside of the support of her husband) for the bride upon her arrival. Drawing attention to these two characteristics of the mail-order marriage exposes the potential vulnerability that the mail-order bride is put in. She is dependent on her husband to stay in the (developed) country she has immigrated to, and often has no one but her husband to rely on for information about this new place.

Some scholars who are against the term "mail-order" to describe the marriage have resorted to new terms such as "marriage correspondence," "transnational brokered marriages," and "international matchmaking" (D'Aoust, 2009,3$).{ }^{4}$ Nicole Constable, who uses the term "transnational brokered marriages" in her work, will not use the term mail-order bride because she feels it has the negative connotation of commoditizing women (Constable, 2006, 168).

\footnotetext{
${ }^{4}$ These terms are used respectively by Nicole Constable, Kathryn Robinson and Lisa Anne Simons.
} 
These new expressions are thought to represent the choice and agency that the women practice rather than carrying the derogatory connotations of being bought and sold that the term "mailorder" suggests.

In some ways, the choice of these alternative terms makes sense. For one thing, most women involved in these relationships do not think of themselves as mail-order brides. It is a term that others place on their relationship without acknowledging that it may be the same as any other marriage (Constable, 2003, 6). Secondly, using the term "mail-order bride" creates an image of a woman who has been bought, not one who has taken the time to create an online account and communicated with a man for a while before deciding to marry. Instead, it assumes that any man can choose exactly what woman he wants without any opinion or options given to the woman whom he is marrying.

Many scholars use the term "mail-order" without questioning it or considering the reservations others may have with it. It is well recognized and popularized in society and the media. For example, a Google search for "mail-order bride" provides 2,140,000 hits; a search for "international matchmaking" results in 310,000 hits where the top few sites are broad and not specific to the phenomenon being discussed. This does not mean that the term correctly describes the women or the relationship it defines, but it serves the purpose of naming a particular phenomenon that has a popular conception in our society. Anne D'Aoust correctly points out that while the other terms used by scholars might be less offensive, the popular term mail-order bride has come to emphasize a specific type of relationship to the public $(2009,4)$. Couples involved in international marriages, transnational marriages, or those who have corresponded before marriage do not all fall into the definition of mail-order bride (D'Aoust, 
$2009,4-5)$. The term mail-order bride is used to identify a specific, more precise group of women.

\subsubsection{Characterizing the Mail-Order Bride}

Although a specific definition for mail-order brides may be useful, it is not enough to create one general formula for determining who decides to becomes a mail-order bride. Academia has painted the picture of two different types of women who engage in mail-order marriages. The one favored by Langevin and Belleau, Alcuitas-Imperial et al., and many other authors is that of a desperate woman: driven to marry a stranger in hopes of a better life. Langevin and Belleau outline a portrait of a mail-order bride stating that she is interested in improving her living condition and may have personal motivations such as romance in mind (2000, 79-81). But, when discussing why a woman becomes a mail-order bride, they look exclusively at the inability of these women to enter Canada any way other than as a sponsored under the family class $(2000,144)$. This portrayal of mail-order brides suggests poverty, little education, and hopelessness.

Alternatively, the mail-order brides discussed by Constable are depicted as powerful, educated women making conscious decisions about their lives. The women discussed by Constable, who are from the Philippines and China, seem happy, self-motivated and in control of their own destinies. They have made compromises with their husbands about where they should live and how much they should work, and are clearly valued partners in marriage (Constable, 2003, 13-30).

While both sides of the argument generally claim that mail-order brides are not a homogenous group, their analyses do not reflect this. Authors seem set towards biasing readers 
with a one-side perspective instead of examining the different possibilities and ways of being for mail-order brides.

\subsection{Why do Women Become Mail-Order Brides?}

\subsubsection{Global Economic Vulnerability}

A study done by the Philippine Centre of British Columbia found that the main reasons that mail-order brides chose to migrate was because of economics and poverty (Alcuitas-Imperial et al., 2000, 43-44). This is seconded by Langevin and Belleau who argue that "deep poverty, malnutrition, high unemployment" at the individual level, and "heavy foreign debt" at the national level, are the primary factors for becoming a mail-order bride; love is secondary (Langevin \& Belleau, 2000, 90).

Because of place of birth, men in mail-order marriages seem to have the upper hand in the relationship. The unequal power relationship between the men and the mail-order brides begins during the courtship period, prior to marriage, when the couple is getting to know each other. The husband is estimated to spend between $\$ 10,000-15,000$ in matchmaking fees on top of being responsible for his bride's plane ticket over to his home and the $\$ 550$ permanent resident visa fee imposed in Canada (CIC, 2008). Different agencies have different ways of providing match-making services. Some require a set monthly fee whereas others charge per address that the male asks for. There is an array of different services available, such as "bridal tours", where a man can go and meet with many different women and from them select his wife. Some agencies offer 'wedding kits' complete with instructions on how to immigrate. On a smaller scale, some agencies have services such as delivering flowers and mailing love notes on behalf of the male. 
Unlike the men, women access the mail-order bride websites for free (Langevin \& Belleau, 2000, 100). They are not expected to spend any of their own money but it has become a common practice for the husband to send money to his bride and her family while they are courting (Alcuitas-Imperial et al., 2000, 25). Although it may not be much money in Canada, a small amount can go a long way in the Philippines. The continual sending of gifts and money creates expectations that the woman will marry the man because he has 'invested' in her and her family. It also heightens the inequality of the relationship in financial terms as the husband has paid to meet the bride online and has continued to pay for gifts. This has the potential to create a scenario where the husband feels as though he has "bought" his wife. Any sense of ownership or entitlement towards women is harmful and in the worst-case scenario may result in these brides being held in debt-bondage by their husbands once they are married (Langevin \& Belleau, 2000, 103). Although these women have a choice as to which men they respond to, it is the men that always make the initial contact. This gives men more power and leverage as they make the initial decision to only contact those that they are interested in. The women have to hope that of the people who contact them there will be someone they are interested in.

As mentioned in the introduction, the Philippines economy has not done well in recent years and continues to rely on remittances rather than sustaining itself through its national resources and industries. These external factors influence all Filipinos, not just the women that become mail-order brides. They create larger global disparities that also play a role in the economic vulnerability of women.

The disparity between the mail-order bride and her husband must be examined as both global and individual issues. One mail-order bride believed that if she had not been sending money home her parents would probably have died prematurely as they would not be able to 
afford medicine and medical care if it were not for her sacrifice in moving abroad (AlcuitasImperial, 2000, 43). This demonstrates the blurring of individual and global factors. Because of the global factors, Canadian money goes much further in the Philippines. This has very real consequences for individuals who are able to provide for their loved ones by going abroad. Langevin and Belleau state that the main factor motivating international migration is that "brides experience serious difficulties meeting their basic needs in their countries of origin" $(2000,91)$.

Because of the "gift" of a life in the Western World, a mail-order bride may sacrifice her ability and desire to work outside of the home. Staying at home may be because their husbands wish that they do, or because their qualifications are not recognized in Canada. Nicole Constable suggests that many mail-order brides are educated, some even more than their husbands (2003, 78). Her research has found mail-order brides to be choosing to marry foreigners out of choice and not as an option for dealing with acute poverty (Constable, 2003,3). She is vehemently opposed to mail-order brides being viewed as passive or as having controlling husbands (Constable, 2003). Her research and comments suggest that women choose to be mail-order brides, and that due to the high educational backgrounds of many of the women, individual disparity between mail-order brides and their husbands may not be so severe on an individual level.

\subsection{What Vulnerabilities do Mail-Order Brides Face?}

\subsubsection{Immigrating to Canada as a Mail-Order Bride}

Immigrant receiving countries such as Canada have highly selective immigration systems. Their immigration systems tend to advantage some and disadvantage others in the selection process. The immigration system in Canada divides immigrants into three classes: 
economic class, family class, and refugees. This classification determines both the entry of immigrants and their status/treatment after they arrive in Canada. The first stream, the economic class immigrant must obtain enough "points" from a rubric consisting of categories including education and language skills in either of the official languages to enter the country. With the Canadian immigration point system implemented in 1967, applicants are accepted or denied based on their ability to fulfill requirements such as a high level of education, proficiency in either or both official languages, work experience, as well as the necessity to pay permanent landing fees and flight costs to arrive in the country (CIC, 2010). A second stream, the family class, allows people already in Canada to sponsor their next of kin to join them in Canada with a promise of financially supporting them for a minimum of three years, so they are not a burden on the state. Finally, there is the refugee class, consisting of those that have left their homes because of fear of persecution. The entire process of immigration is intended to provide the country with more skilled laborers. It therefore tends to encourage those who are expected to perform well in the labour market.

The Canadian immigration process is thought to favor males as the more likely candidate in the economic class because the "skills" which are listed and valued highly do not in any way look at skill and work involved in the domestic sphere, long associated with women. As education and language acquisition are options only for those with money and are in many countries reserved for men, the poor are immediately disadvantaged within the Canadian immigration system, and poor females even more so (Langevin \& Belleau, 2000, 144). These characteristics of the immigration process leave few avenues for women who are not highly educated or do not have specifically recognized "skills" to migrate out of a developing country into a developed one. In this context, becoming a mail-order bride provides a legally legitimate 
method of doing so. Unfortunately, getting into a developed country is not the end of the journey as difficulties and vulnerabilities facing female migrants will likely follow these women for as long as they live in Canada.

Under Canadian immigration policy, as a spouse, one must reside in Canada for three years before the period of sponsorship ends and they become immigrants in their own right (CIC, 2010). Once a woman is no longer obligated to have a sponsor, she is granted the same rights to social welfare as any other Canadian citizen, which would allow her the opportunity to leave her husband were she unhappy with their marriage. Until that time, ending the marriage may result in deportation, keeping the bride vulnerable as she may feel obligated to shut up and put up with an abusive relationship. Lindee sums up the dilemma faced by mail-order brides in abusive relationships:

"(I)n conjunction with their greater economic and social power, consumer husbands possess "real and imagined" power to allow mail-order brides to immigrate to the US [or Canada] and then threaten deportation and arrest once she is here" $(2007,561)$. Spousal abuse is illegal under the Criminal Code of Canada (Langevin \& Belleau, 2000, 175). In cases of abuse, leaving one's husband during the three year sponsorship period does not automatically lead to women being deported (Alcuitas-Imperial et al., 2000, 26, 32). However, as the language in the sponsorship contract makes it sound like a three-year relationship is an absolute requirement, it leaves the information regarding women's rights in regard to their sponsor ambiguous. This ambiguity increases the fear women feel about speaking out against violence. Furthermore, women are often uninformed about their rights, or too concerned about the financial and other consequences of divorce to seek legal help. Especially of women have migrated because of poverty, they may be willing to put up with abuse if it means not being able to send money home. 


\subsubsection{Economic Vulnerabilities Faced by Mail-Order Brides}

In many cases the mail-order brides have arrived in Canada to full-time jobs at home for no pay. Children from a previous marriage or a chronically ill husband may result in the mailorder bride never having the opportunity to leave the home and work as her husband would demand a wife that will put her family first. In one case, a Filipino mail-order bride married a quadriplegic who required full-time care (Glodava \& Onizuka, 1994, 57). Because of the perception of Filipinas being "domestics" and the appeal of mail-order brides for their traditional family values, these women are given work at home without pay.

The mail-order bride may feel it is her responsibility to work at home while her husband makes a living for the family. It is not uncommon for a mail-order bride to immediately take on the responsibility of caring for her husband's children from a previous marriage, aging parents, or the husband himself. These immediate responsibilities do not allow time for language training even if it would improve the bride's quality of life. Feeling obligated to take on household duties immediately may be linked to the pressures created by sponsorship as sponsorship "exacerbates their unequal status within the marriage, diminishes their dignity and degree of independence, aggravates existing socio-economic disadvantages and violates their most basic human rights" (Walton-Roberts, 2004, 270).

According to a study of 40 subjects, $48 \%$ of Filipino mail-order brides in Canada have been able to work outside of the home as a way to earn money for their family of origin (Alcuitas-Imperial et al., 2000, 39). This is a lower percentage than the average of all Canadian women working outside of the home. Although this is a small sample to be working from, it demonstrates that not all mail-order brides are forced to work at home without pay and may live 
a life where they are not completely dependent on their husbands. Even though the economic benefits of an overseas marriage are very important to these women, disputes over sending money home are common (Alcuitas-Imperial et al., 2000, 53). Undoubtedly, this can add a financial strain to a mail-order relationship because of the different expectations and different understanding of the goals and the values held by both partners. The mail-order bride may be kept economically vulnerable, limiting her ability to send remittances freely.

Even when allowed to work outside of the home, it has been found that mail-order brides "are often relegated to low paying, insecure, un-skilled work with little government protection" (Pehar, 2003, 172). These poorly paid jobs do not break the cycle of economic vulnerability. The Filipino mail-order brides that do procure work outside of the home often continue to be dependent on their husbands. These women are kept in a vulnerable position where they must please their husband to be able to send money home (Langevin \& Belleau, 2000, 109). In cases of abusive relationships, Filipino mail-order brides do not stay for their own economic wellbeing, but because their family in the Philippines relies on their remittances (Langevin \& Belleau, 2000, 109). While acknowledging that stakes may be higher for mail-order brides, it is important to note that continual dependence is problematic for any marriage because "women whose dependence on their marriage is high and who have few resources with which to negotiate changes in their husband's behavior are more susceptible to prolonged physical violence" (Narayan, 1995, 109).

Ownership in any relationship between humans is harmful. Some husbands do not seem to think of getting a wife very differently from any other purchase they may make. They agree with the idea that the mail-order bride trade commoditizes women and have no issue with placing a price on relationships and women in general. One husband was pleased to report that 
buying his wife cost less than purchasing an economy car (Lindee, 2007, 553), as though she was no different from any other possession. An Australian man had decided to 'purchase' a wife "because it was cheaper to get an Asian wife than to get an Australian prostitute (Lindee, 2007, 567)." Although it is not my wish to stereotype all mail-order relationships, I believe that there is a higher chance in these relationships of wives being forced into a submissive position because of a belief that they 'owe' their husband something or that they have no option out of their relationship.

\subsubsection{Social Vulnerabilities Faced by Mail-Order Brides}

As a result of having a Canadian spouse, mail-order brides are accepted into Canada as family class immigrants. Family class immigrants are expected to be supported by family upon arrival. While in theory having a husband should be adequate support, the situation is strained by the fact that the husband and wife have likely not lived together before and may not even know each other very well. For the most part, mail-order marriage relationships are built through emails and phone calls, and the occasional visit, if the couple is lucky. Therefore, while entering Canada as family class immigrants, mail-order brides are a class to themselves. In contrast to many other family class immigrants these women may arrive with little acquaintance or knowledge of their husband and/or his family, who are not only expected to financially support her but would normally be the ones to help acculturate the new immigrant. While she may not know her husband well, the women may have no one else to turn to for support.

Although it is not surprising that most mail-order brides have no family members in the country (Alcuitas-Imperial et al., 2000, 56), it is surprising that unlike most immigrant women, mail-order brides do not turn to their community for support (Langevin and Belleau, 2000). This 
is perhaps because they are often stigmatized or ashamed of their position as mail-order brides and not accepted within the community. Some scholars argue the Filipino diaspora places a stigma on all mail-order brides, limiting the support they would receive from other immigrants (Menjivar, 2002, 906). Although it should be impossible to detect a mail-order relationship on the outside, women have reported that they feel self-conscious in public as their husbands may be significantly older than them, causing people to think of them as having a 'sugar daddy' - a man who is rich and gives women expensive gifts in exchange for sexual favours (Langevin \& Belleau, 2000, 110). The discomfort they feel in relation to their ethno-cultural community increases the vulnerability of Filipino mail-order brides as they may have only their husbands to rely on.

\subsubsection{The Human Trafficking Discourse and Mail-Order Brides}

Some scholars and public policy discourses suggest that mail-order brides should be seen as part of human trafficking because of the uncertainty of how much 'choice' they had in moving away from their families. For example, Ninotchka Rosca, a Filipina activist, states that "the thin line between servant and prostitute is bridged by the mail-order bride" (cited in Alcuitas-Imperial et al., 2000, 4). It has been suggested by Vanessa B.M. Vergara that if their relationship deteriorates, the American Thirteenth Amendment against slavery may be applicable to mailorder brides $(2000,1548)$. Others, such as Mila Glodava and Richard Onizuka, see mail-order brides relationships as sexual exploitation that should be stopped $(1994,121)$. Perhaps the strongest argument of mail-order brides being a form of human trafficking is expressed by Beverly Encarguez Perez who likens the mail-order bride "trade" to that of slavery as it is a continuation of human capital being exchanged for money $(2003,220-221)$. 
It is true that there are some unknowns in a mail-order marriage, for both the groom and bride, although it is often the bride that is in a more vulnerable state. It is also true that some mail-order bride agencies engage in deceptive measures, such as writing letters on behalf of their male clients, leading to unrealistic expectations by the women (So, 2005, 407). There are also examples of severe cases, such an American man "divorcing" his wife, although they continued to live together, so that he could get a mail-order bride who would cook and clean for them for free (Lindee, 2007, 567). Incidents such as these can indeed be considered as part of the human trafficking trade because of the deception involved in luring women to a different country where they may be too embarrassed or ashamed to return to their home country.

Contrary to this, it should be pointed out that the experiences of mail-order brides are not always characterized by violence and abuse. Nicole Constable has written that the "South to North migration narrative is troubling because it lends itself too easily to the logic of a trafficking discourse, to a view of women as victims, and to a fundamentally anti-immigration stance" $(2006,4)$. Scholars who object the view of mail-order brides as victims of human trafficking often point to the willingness of women to participate and to the fact that they are informed of the potential dangers of marrying a foreigner by the Overseas Philippine Commission (Constable 2006, 12). This would suggest knowledge on the part of women of their potential vulnerability and that the fact that they decided to move of their own free will and were not directly forced.

It is important to highlight that the differences between women cannot be ignored. It is possible that some mail-order brides are victims of exploitative abuse, but not all of them. This leads to difficulty in law-making in imposing general regulations on the migration of these women, as some may be victims of human trafficking and others are not. There is a need by 
scholars and law makers to recognize that it is possible to both have a choice and still be vulnerable as this is the case for many mail-order brides. Even when these women are choosing to immigrate of their own freewill, there are still obstacles and barriers in being able to practice the same rights as other Canadians. They cannot all be lumped together because of the vast differences in their situation, based on who they are marrying, the reason they have chosen to marry, and their ability or willingness to return home if the situation is not acceptable to them. Even in the case of "trafficked persons", whose status as such is not debatable, it is noted that most want to migrate, that it is not an issue of being forced against their own will (Kempadoo, 2005, 38). Furthermore, some women are seen as in control as "self-determining, differentially positioned subjects who are capable of negotiation" (Kempadoo, 2005, 37). These arguments suggest that women migrating from the Third World are not ignorant of the dangers that face them and do not need to be treated as perpetual victims. What is disturbing about the trafficking discourse, however, is that the laws put in place to "protect" these women tend to criminalize them (as well as the traffickers) and expect that they will return home (Kempadoo, 2005, 41). Instead of providing a framework through which women could be helped, anti-trafficking laws generally scare true trafficking victims away from seeking help, pushing them underground, and therefore increasing the precariousness of their situation (Kempadoo, 2005, 41). All debates regarding mail-order brides must be nuanced as there are significant differences within this category of women. Mail-order brides should not be viewed universally as victims. Laws should reflect the fact that these women did not ignorantly make the decision to move. 


\subsection{What is Being Done to Help Mail-Order Brides?}

\subsubsection{Laws Pertaining to Mail-Order Brides}

With some of the vulnerabilities outlined above, a question to pose is how are these women being protected? For the most part, the mail-order bride trade continues to be unregulated (D'Aoust, 2009, 8). Canada, along with most other countries, has not made any attempt to systematically study or to regulate the special case of mail-order brides arriving in Canada as part of the family class (Abidi and Brigham, 2008, 24). In the immigration process, there is no differentiation between foreign brides for the purpose of record keeping. This makes it very difficult to gage the success or difficulties this group of women may experience in Canada. As it is always difficult to track individuals, it has been the regulation of mail-order bride agencies that have become the more typical way of intervening in the mail-order bride relationships. Below, I discuss the cases of two countries that have tried to regulate the movement of mail-order brides: The Philippines and the United States. In both cases this has been done largely through attempts to regulate international marriage brokers (IMBs) which are the agencies that connect the First World men to the Third World women. These two countries have taken different approaches in an attempt to keep their citizens and country safe.

The Philippines, the Asian country with the largest number of mail-order brides, has been a leader legislating in the area of mail-order brides (Sims, 2009, 615). In 1990, the Republic Act 6955, known as the Mail-Order Bride Law, banned mail-order bride agencies in the Philippines after murders occurred in Australia and the United States (Perez, 2003, 232). The acts of profiting from match-making a Filipino woman to a foreigner, advertising mail-order bride services, or attempting to recruit mail-order brides became punishable by six to eight years in 
prison and/or a fine of eight to twenty thousand pesos (Sims, 2009, 616). The law was enacted as a way to protect Filipino women. Over time it has become linked to the Philippine's AntiTrafficking in Persons Act of 2003, which declares businesses that enable foreigners to marry Filipino women as an act of human trafficking (Sims, 2009, 619).

The laws put in place in the Philippines have largely been criticized. For one thing, the law has not had the desired effect of limiting the number of women leaving the country, as Roxana Sims estimates that 10 million Filipino women have left their country to become mailorder brides since 1990 when the law was put in place $(2009,618-619) .{ }^{5}$ The legislation has proven difficult to enforce as the Philippines does not have jurisdiction over what is put on the internet outside of their country. Based outside of the Philippines, these international marriage brokers go unpunished and continue their business the same as they did before the law was passed (Langevin \& Belleau, 2000, 80, and D'Aoust, 2009, 8). Within the Philippines, mailorder bride agencies continued to exist after the Republic Act. No. 6955 was passed by becoming "pen pal" agencies where women could meet foreign men, although nothing of marriage is specifically mentioned (Langevin \& Belleau, 2000, 80, D'Aoust, 2009, 8). Finally, as the women choose to be advertised on the internet, suing companies for solicitation is difficult (Morgan, 2007, 5-6). Given the ineffectiveness of this legislation in actually preventing the migration of women as brides or protecting them, it seems that the law was meant as a symbolic public relations gesture to make the government look like it protects women.

Although unsuccessful, the Philippines have attempted to help the women who are viewed as vulnerable subjects in need of protection. They are the only country that has banned

\footnotetext{
${ }^{5}$ Sims is the only source which provides an estimated figure for the total number of women to have left the Philippines in recent decades as mail-order brides. As there are no other sources which provide information on total numbers, I have no way to assess whether this figure is a conservative or overstated estimate.
} 
the mail-order bride industry completely despite the fact that the majority of mail-order brides in the world continue to originate from the Philippines (D'Aoust, 2009, 8). Other governments, those in the receiving countries, have taken different approaches. In the United States, the concern regarding the mail-order brides coming into the country is expressed through the 2005 International Marriage Broker Regulation Act (IMBRA). This act requires that marriage brokers perform background searches on their male clients to see if they are a sex offender or if they have been convicted of specific crimes that would affect their partner, such as homicide and stalking (Sims, 2009, 620).

It has been suggested that the United States government's interest in mail-order brides is in part related to the fear of both fraudulent marriages and the "privatization of citizenship" (D'Aoust, 2009, 2). "Privatization of citizenship" entails people being able to pay their way into the country, in a sense 'jumping the immigration line' by having enough money to pay for a false marriage. As the largest group of immigrants entering America is from the family class, it is not surprising that the validity of these relationships might be questioned. This would suggest that rather than the protection of women, it is instead the protection of the state that is the goal here. To this end, it is possible that the legislation is more about keeping people out of the country rather than providing meaningful protection for these women once they have arrived in the United States. I am convinced that before the marriage takes place it is crucial to have some information, such as the required criminal check, as a precaution. This, however, is a minimal form of protection. Not addressed through legislation are several forms of vulnerability that may not emerge until women are settled in their new homes. It is assumed that if a man does not have a previous criminal record then he will not be abusive. Unfortunately, this is far too great an assumption. In no way addressed by this legislation is the question of how the structural 
vulnerabilities of the brides can lead to exploitative or abusive behavior on the part of the husband.

Because of the difficulty in calculating the number of marriages based on "mail-order" relationships, it is difficult to assess whether the IMBRA has been successful in preventing abuse for mail-order brides entering the United States (Sims, 2009, 621). One must also question whether or not the law can be very effective, as there have been cases of agencies advising their male clients to not share information about their violent histories of abusing women (Lindee, 2007, 562). Despite the limitations of the legislation, the placing of the IMBRA under the Violence Against Women Act, instead of under the Trafficking Victims Protection Act (TVPA) demonstrates that, in the United States, mail-order brides are viewed less as human trafficking victims and more as individuals needing protection (D'Auost, 2009, 17 and Lindee, 2007). This is in contrast to the approach the United Nations has taken, which has been to group human trafficking under the office of Drugs and Crimes, ignoring the fact that in reality human trafficking is closely related to immigration. 


\section{Interviews with Organization Representatives}

\subsection{Interview with Eve}

Eve has been a settlement worker within the Filipino community for over 20 years. Throughout her time in the field, she has been in touch with many mail-order brides. She considers the injustices mail-order brides suffer to be similar to those of migrant workers. She regards both forms of migration to be forms of human trafficking. In her opinion, like migrant workers, mail-order brides are too dependent on someone else for their ability to stay in Canada.

\subsubsection{Who are Mail-Order Brides?}

According to Eve's observations, there have been more women who arrived in Canada as tourists and then tried to procure a husband than people who had met over the internet. It is through contacts provided by immigration consultants that these women find men willing to marry - though often for a price. This group of women, coming over to Canada on their own and then paying a man to marry them, represents a complete reversal of the scenario described by Langevin and Belleau where the husbands may feel ownership because they have "bought" their wives by paying for them to come to the country $(2000,100)$. Eve cautioned that these women could still be vulnerable as they were dependent on their husband to stay in the country. As with other mail-order relationships, this makes leaving the marriage extremely difficult as it may result in women being forced to return to the Philippines.

To enter the country, these women would often come as visitors. Eve stated that in the Philippines it would look less suspicious to be coming to Canada as a tourist if you had already done significant travel and if you had a steady, well-paid job. Tourist visas for Canada were

\footnotetext{
${ }^{6}$ Names of the two interviewees have been changed in order to not expose their identities, and to prevent possible recognition of the people they have talked about.
} 
valid for up to six months, and then could often be renewed for an additional six months. This would mean that over $50 \%$ of the women that Eve came in contact with were highly educated, well-paid professionals that could afford to travel. At the same time, though, Eve believed that economic motivations were likely behind these women moving away from the Philippines.

\subsubsection{Why do Women Become Mail-Order Brides?}

Eve was convinced that all women that become mail-order brides do so because of economic reasons. In addition to those who came to Canada as tourists and stayed as a result of marriage, Eve has also come in contact with women that met their husbands over the internet, and then come to Canada as mail-order brides. This group, according to Eve, tended to be significantly poorer.

\subsubsection{Vulnerabilities Faced by Mail-Order Brides}

The women who meet their husbands over the internet often have fewer resources than those that come to Canada to find a husband and may be lured over the internet with the promise of a more comfortable lifestyle. As outlined by other authors in the literature review, once in Canada, they are extremely vulnerable and there are different forms of abuse these women may encounter. Eve believes that one of the ways women are kept the most vulnerable is by never being given the opportunity to leave their husband's side. This is especially true if a woman is brought to a rural area, where it is quite possible that the husband would be able to keep his wife from interacting with anyone and would prevent her from receiving information about her rights within Canada.

Women with more education are more likely to be embarrassed of their accented or grammatically incorrect English. As a result, Eve believes that it is the more educated women 
that depend more on their husbands to communicate on their behalf. Because of this, these women are less likely to be assertive and demand changes in their relationship out of fear. According to Eve it is often the educated women that are more sensitive and observant about the unequal power relationship between the couple whereas mail-order brides that have had less education may accept relationships at face value and be more vocal about wanting changes.

As the above paragraph suggests, it is not the case that higher education guarantees better status for mail-order brides. Eve shared with me a story of a man who kept continually calling her asking why it was taking so long for his wife to emigrate from the Philippines. The woman in question was a highly trained professional. Eve tried to assure him that everything was in order and that immigration is often a slow process but there was no reason to worry. The man continued to call and was not able to be appeased. He finally stated the reason for his agitation: his health was quickly deteriorating and he was in desperate need of full-time care. His reasons for marrying were to procure a personal nurse. This story tells of someone who is highly educated, likely aware of her husband's motivations for finding a wife, and still choosing to come to Canada as a worker under the pretense of having a marital relationship.

There is a fine line to consider of whether this case, a woman marrying a man who is dying so that she can be his caregiver, is one that can be considered a legitimate form of marriage or if this is a way of jumping the immigration line by falsifying a relationship. The relationship between these two individuals seems like more of a short-term work contract where the salary was to be room, board, and Canadian citizenship. Although I do not know the particulars of the arrangement between the man whose health was quickly deteriorating and his wife, such as how long he had to live and if his wife would be the sole person to inherit his estate after she would have cared for him while he died, this could be a very strategic move for both 
husband and wife. The husband can be sure that he receives good care or he would divorce his wife and she would be sent home to the Philippines. On the flipside, she lives as an employee for a few years and in return may be given Canadian citizenship, a home, and life insurance as her reward.

In a scenario such as this, where it was clear that the husband was searching for domestic help and that his wife was privy to this information, mail-order relationships could be advantageous for both parties involved. But, according to Eve, it is not uncommon that many physically or psychologically handicapped men use mail-order bride websites to find women to marry and that the majority of these women are not aware of the full extent of their husbands disabilities and that they will be caring for their husbands instead of having the option of working outside of the home. Although in some cases this may be mutually beneficial, as the husband has procured free labour and the wife is given a new life in Canada, if a woman is presuming she will have the freedom of choosing her employment, it could be a severe vulnerability to be unknowingly saddled with an invalid husband without knowledge of it before hand.

Consistent with the writings of Langevin and Belleau, Eve believed that for mail-order brides, there was often pressure from their family to move away. Remittances from Canada or the United States could go a long ways in the Philippines towards helping a family pay for higher education or domestic help - in fact the GDP of the Philippines relies upon it. The benefit of being able to live well in the Philippines on money that is considered rather small in North America is known both by the husband and wife. This, according to Eve, is often the biggest or the only push factor for becoming a mail-order bride. 
Another issue brought up by Eve that is not discussed by most scholars is that some women are willing to come to Canada without getting married and live in common-law relationships. This would seem to be the opposite of claims expressed by Langevin and Belleau that mail-order brides are generally very religious and that this was one factor that kept them in unhappy marriages because they would do anything possible to avoid divorce $(2000,91)$. Coming to Canada to live as domestic partners demonstrates the diversity of behaviors that is often ignored not just among mail-order brides but in the Filipino population in general. Just because there is a significant Catholic population in the Philippines does not mean that everyone is bound by the same religious rules.

\subsubsection{Positive Experiences}

After hearing of numerous instances of abuse, I asked Eve if she had come across any positive mail-order bride relationships. She stated that of course she had, but that these were not the ones that required attention. Regarding state protection, there is no way to predetermine which couples will face abuse, requiring us to provide protection for all of them.

There are cases where couples have done successful financial planning whereby the situation is mutually beneficially to the husband (who may not have significant resources) and the wife. In these cases, the woman is not the victim that most presume mail-order brides to be. Nicole Constable shares a story of one woman that she interviewed whose husband had moved to the Philippines once they were married (2003, 25-27). Eve believed that for roughly $\$ 3,000$ a month, a husband and wife could live very nicely near the ocean, with plenty of wonderful food, and with hired help to do the household chores and cooking. These relationships signify both the husband and wife being active players in the relationship and coming to compromises that suit 
them both. Also, this sum of money is attainable for retired working class men. Although men marrying mail-order brides are often profiled as wealthy by Filipino standards, in reality they may be blue-collared workers. The relationship, however, can be mutually beneficial. Not only would they benefit as living in the Philippines with what might be considered rather limited income in North America would be far superior to what either partner could afford alone in their respective countries of origin, but the husband also gains someone who knows the language and the culture to help guide him.

\subsection{Interview with Lydia}

Lydia has been working as an activist within the Filipino community for many years, and during this time has come to know seven mail-order brides personally, as well as having heard stories about many others living in Canada. Her opinion is that the women that become mailorder brides are often educated but unable to find appropriate work with decent compensation in the Philippines. Coming from both urban and rural areas, women who consider being mail-order brides have experienced "deep poverty" and are looking to better their lives economically.

\subsubsection{Who are Mail-Order Brides?}

Lydia, like Eve, challenges the definition of mail-order bride. She believes that the traditional definition should be expanded to include marriages that happen quickly, when there is no previous communication between the parties and when a man goes to the Philippines with the purpose of bringing a bride home. She called for a new, gender-neutral, term to be created as, she said, it is not uncommon for Filipino women living in North America to return to the Philippines and marry as a way to help a man leave the country for a better life. 
Lydia is in contact with a couple, Joseph and Clara, who do not consider themselves to have been a part of a mail-order bride relationship. Joseph, a Canadian, went online and contracted an agency to find some female friends, and of these friends met Clara, his wife. This couple would fit into the traditional definition of a mail-order bride relationship outlined in the literature review, but they are uncomfortable with the title of 'mail-order bride' because they consider these relationships to not involve loving each other. This indicates that, like Nicole Constable, some people think of "mail-order bride" as an offensive term that holds negative connotations, one that predisposes onlookers to presume that the relationship is one of inequality and dominance, where one spouse makes all of the decisions and controls the other one.

\subsubsection{Why do Women Become Mail-Order Brides?}

According to Lydia, becoming a mail-order bride is always linked to the need of money. From what Lydia has observed and heard from those in the Filipino community, she has come to the conclusion that it is the Filipino government that should be blamed for both the cultural and economic hardships mail-order brides suffer. Lydia compared the structure of Filipino society, which is largely still feudal, to their place within the global context. Within the rural areas of the Philippines, there continues to be a system where wealthy land owners rent small plots of land to others who rarely are able to make ends meet. To pay off the family debt, it is not uncommon for a daughter to work in the landowner's home. In a similar way, because of the international debt the Philippines suffers as a nation, it is the women that are being forced to work abroad to pay off what is owed by the government. For this reason, the sending of remittances is very important to the county. While it is the families of the mail-order brides that rely directly on this money, the Filipino government is indirectly expecting to prosper from it as well. 


\subsubsection{Vulnerabilities Faced by Mail-Order Brides}

It is particularly stressful for Filipino mail-order brides to, on the one hand, be expected to send money home to their families, and on the other hand, experience situations where they are not allowed, or do not have time, to work outside the home. Lydia succinctly summed up some of the problems with a mail-order relationship. The first problem of mail-order relationships is that there are unrealistic expectations on both sides. The man is looking for free labor ("or why else get a bride from the Philippines?" Lydia remarked), whereas the woman is looking for increased freedom, comfort and income as she is now in a First World nation. Lydia explains it as a relationship of mutual exploitation. The men are looking for a slave, whereas the women are trying to use the man for a passport. Both are often disappointed with what they find, but it is usually the women that have more to lose. Whereas the men often succeed in getting free labour from their wives, the women are not always so lucky about getting their higher standard of living and extra money to send remittances.

As mentioned, working is particularly important because of the need to send remittances home. Lydia points this out as a second issue in mail-order relationships that can create tension. Many North American men do not realize that in the Philippines "you never just marry your wife, you marry the whole family." The wife will be under significant pressure to continue sending money home because she is now in North America and assumed to have a comfortable lifestyle. This, however, is not always understood or accepted by the husband. Like in any other relationship, but especially in relationships between two people of different cultures, there is bound to be some differing expectations that must be worked out. The problem specific to mailorder bride relationships is that it rarely consists of two equal partners; there is generally one spouse who holds most of the power and is given the right of making all of the decisions. 
Lydia also places the blame on Filipino society and state as a whole, not just on the families of those that pressure their daughters to move abroad to help support the family. It is the government that encourages this practice by not securing more industry within the country. Socially, within the Philippines, many decisions are made at the family level where the children have little say in the matter. In some families, it would be expected that you would help make money for the family. If one cannot find a job even with education, then moving abroad is a viable option.

Within the family structure, Lydia states patriarchal expectations dictate that that "the man is the king of the house, and his wife must follow along and satisfy his needs." Women are dependent on their husbands and fathers from an early age. The compliance with patriarchal patterns is evident in women who expect and try to please their husbands, particularly to the point where they fear standing up for their rights. Lydia claims that it is in part a cultural norm to fear those that have authority over you, especially if that person is a man. She noted, however, the unequal power relationship in marriages in Canada is based on other factors and dynamics, as one is sponsoring the other to come to Canada and the sponsored one is a dependent for at least three years. This allows the sponsor, usually the man, to make many of the decisions even if it is not what his wife wants or was expecting.

It is not always the case that the couple will have a lot of spare money to send back to the Philippines. For instance, Lydia cited a man that sponsored his wife to come to Canada while he was on welfare. According to immigration rules, no one is allowed to sponsor someone while they are on welfare, but through some bureaucratic error his wife was able to come to Canada. Upon arrival his wife was on welfare for a brief amount of time until the government realized their error and the couple was obligated to repay the government for the money paid to the 
sponsored party this money back. More than the controlling character of the husband, Lydia suggested that the inability to send money home may be based on economic challenges the couple faces.

Unfortunately, from Lydia's observations, there are some couples where extreme limitations are put on the bride. For instance, Janet was not allowed to use the phone; she was not allowed to work or given any type of allowance; and she suffered from domestic abuse. She was always at the mercy of her husband, a Filipino-Canadian who had gone back to the Philippines after a divorce to try and find a new wife. She was dependent on her husband for money to send home to her family.

In these severe cases, Lydia noted that there was often very little outside support that women could hope to find. This is in part because it is so hard to know about or to reach women who have no freedom to interact with others. Lydia believes that these women tend to rely on the Catholic Church and faith, not on other people, as they hope to turn their relationships around. Despite the absence of support, Lydia thinks that in general the Filipino community does not pass judgment on these women who have decided to come to North America as they have mostly likely also suffered from the general poverty of the Philippines. Reliance on the Church is not a limiting factor unless these women will not leave abusive relationships because they do not believe in divorce.

Based on her community work, Lydia sees the Filipino community as a traditional society of devout Christians that follows the authority of the parents and do not want to deviate from the 'proper course'. From Lydia's experience, even in unhappy marriages, divorce is rarely the solution. Separation is acceptable, but because of the customs and traditions that many of the 
Filipinos were raised with, divorce is not an option once they have taken the sacred oath of getting married.

Lydia could cite only one mail-order bride that had gotten divorced. This woman divorced her husband after he continued to verbally abuse her. Now, this woman has found a new partner; has bought her own house; and leads a stable life in Canada. Unfortunately, Lydia believes this is very rare. As a comparison, Lydia cited a mail-order bride whose husband physically abused her. Even though she called the police and he was sent to jail, she later dropped the charges rather than taking her husband to court. They continue to live together. This, Lydia argues, is unfortunately the more common tale, although this is not unique to mailorder brides, but most marriages where there is a relationship of dependence.

\subsubsection{Positive Experiences}

There is a chance of positive relationships for mail-order brides. Joseph and Clara, the couple who do not view themselves in a mail-order relationship, demonstrate an example of a positive relationship. Joseph got in touch with Lydia before Clara had arrived in Canada. He was living in a rural area, and since there was no one around from the Philippines, he was phoning Filipino organizations hoping to find someone who spoke the same dialect as Clara so that she could make some friends. This thoughtfulness has continued and Lydia has assured me that they are a very happy couple.

\subsection{Comparing and Contrasting the Interviews to Mail-Order Bride Literature}

The most immediate observation I made after interviewing both Eve and Lydia was that, although neither had a suggestion of a better term, mail-order bride as defined by scholars is too narrow to characterize all of the cases that they have witnessed. There is a need for a gender 
neutral term for people who marry someone with the sole purpose of leaving their country of origin. Eve's observation that over $50 \%$ of women married their spouses after they arrive in Canada suggests the need for a broader definition of mail-order brides. The term may have nothing to do with meeting over the internet, but might be about relationships where there is no previous connection between the two people and where the female moves from the developing world to the developed world.

As far as trying to decide which women are becoming mail-order brides, there is no single answer, but some trends can be observed. Because my research is qualitative instead of quantitative, it is not surprising that there are some opposing views on who mail-order brides are and how they are treated as it is based on contact with a few mail-order brides instead of all mailorder brides. There are two main areas in which Lydia and Eve had different opinions. Eve talked of how all Filipinos had been painted as being religious and that in her experience this was not always the case. Despite the country having a majority of Catholics, she did not find that they were always extremely devout and some would be happy to never marry but just live with a man. Opposing this view, Lydia's experience was that the mail-order brides that came to Canada and suffered hardship became even more devout, relying on faith as a source of comfort. This depicts two different types of women, one that is traditional, and sticks to the religious principles instilled by the Catholic Church, and one that is more secular. From Lydia's experience women were willing to continue on in unhappy marriages because the idea of divorce was not acceptable. Lydia stated that from her experience, long-term separations were preferred to the finality of divorce. Although I was originally concerned that Filipino mail-order brides would feel pressured to stay in an abusive marriage because of religious convictions, this does not seem to be a significant factor as separation does not seem to be frowned on. 
A second difference in opinions of the two interviewees is seen in the treatment of Filipino mail-order brides by the Filipino community abroad. According to Eve, there is significant prejudice against mail-order brides and humiliation associated with this. This is supported by Menjivar's and Salcido's findings that mail-order brides are often ostracized by the community $(2002,906)$. In contrast, Lydia claimed that there was an understanding by all displaced people, especially from within the Filipino community because they were all aware of what type of conditions they were leaving. She believed that anyone who knew what it was like to worry about where their next meal would come from would not judge someone else for seeking a better life. If Eve's perception of the Filipino community as not being supportive of mail-order brides is correct, this has disturbing implications for them as it increases their vulnerability significantly. These women may have no community beyond what their husbands may/may not provide for them to go for advice. While this may be fine for some relationships, for others the husband would not necessarily have his wife's best interests in mind.

Although they had some different observations and opinions on who these mail-order brides were and on the attitudes they would encounter from the community, both Lydia and Eve agreed that all of the women coming as mail-order brides have at least some level of formal education. They also agreed that it was solely the hope of economic gain that explained the motivation for the marriages of mail-order brides. It was because of the difficulty in finding work, or how little women were paid for their work that explained why they had to migrate. Although there were many authors, in particular Nicole Constable, who talked of these women as being successful financially prior to migrating abroad, this was not the case for anyone that Eve and Lydia came across. This confirms that mail-order brides come to Canada as a survival 
mechanism. This makes them far more likely to stay in an abusive marriage as there may be no hope of surviving by going back to the Philippines.

Largely, the stories I heard in the interviews were of unhappy couples. I realize that my sample might be skewed. This might be because it is generally people with problems that would be seeking help from organizations. At the same time, it must also be mentioned that those that are subject to the strictest control and the most vulnerable would likely not be given access to services offered. This is especially so for mail-order brides that live in rural areas. Both Eve and Lydia agreed that there have been happy couples but that there are more unhappy couples that should be the main concern of researchers. Both Eve and Lydia were concerned about the vulnerability and control that women experience under the sponsorship system. The fact that another human can decide your fate of staying in the country was very disconcerting to both of them, who see it as a type of ownership over an individual.

Despite the focus of my questions, all relating to mail-order brides, both Eve and Lydia began talking about immigration from the Philippines in general, about migrant workers and the live-in caregiver program which accounts for a large number of female migrants from the Philippines. It became clear from these interviews that mail-order brides are just one facet of a larger, more complex problem. The debt crisis and the burden placed on females to provide for their families are overwhelming problems affecting a significant part of the population in the Philippines. While both Eve and Lydia were sympathetic to the plight of mail-order brides, it was clear that most of their work within the Filipino community was spent elsewhere because of the relatively few that migrate as mail-order brides in comparison to other programs. 


\section{What is to be Done?: Suggestions for Providing Protection to Mail-Order Brides in Canada}

From my analysis, I have come to the conclusion that Filipino mail-order brides are indeed vulnerable and that they are in need of protection from the Canadian government. I have already discussed legal approaches taken by the Philippines and the United States governments regarding protection of mail-order brides. In the Canadian context, the first step towards providing protection would be to start collecting data about mail-order brides in an attempt to understand how many are coming into the country and to identify the issues they face. Based on large-scale quantitative analysis, this data would create a greater understanding of mail-order brides within the country and their needs. The benefits of collecting data would be that the government could provide information aimed specifically for this group of migrants and adjust it based on trends observed, such as country of origin and common forms of abuse.

Unfortunately, collecting this data in any way aside from voluntary participation would be difficult as it is intrusive and people may choose to not share personal information about their lives. Even with voluntary participation, some participants may feel stigmatized and set apart from the group. Despite the drawbacks and challenges of data collection, however, without this data, it is impossible to develop general information about all mail-order brides within the country.

Along with data collection, I suggest criminal checks for past violent behavior on the husband before he is able to sponsor a wife. Most importantly, I believe that more information must be provided to the mail-order bride. Knowing one's rights and one's options, as well as organizations and groups, safe houses and legal aid services, that could provide support and information about one's rights in Canada, would be instrumental for assuring that no one in a vulnerable position is left alone. 
The main drawback of the current system of immigration to Canada for mail-order brides is that marriage failure in the first three years of sponsorship can lead to deportation for the immigrating spouse. If the primary reason that a woman is coming to the country is out of economic necessity, then her willingness to stay in an abusive marriage will be high. Fear of being deported may silence these women from speaking up about abuse, especially if they lack of information about their rights to leave a marriage before the end of the three year sponsorship if they are in an abusive or violent marriage.

Although I am uncomfortable with women being in a marriage for three years before being given the rights of other Canadians, such as the right to welfare, I understand the concerns behind this policy. The state uses this as a preventive measure against fraudulent marriages to try and ensure that these unions are real marriages rather than ones of convenience. While the three-year sponsorship rule may stay, the state also needs to be clear and explicit in announcing that there will not be deportation of the sponsored partner if the partner leaves the relationship because of abuse or violence. The state can also bear additional responsibilities to safeguard the women put in these compromising positions. I would recommend visits to the home, giving these women contacts that they can call if they are in trouble. As with all vulnerable populations, there is no ideal solution that will take away all of the potential dangers mail-order brides may face. It is my hope, however, that enacting these recommendations would help many mail-order brides who otherwise may not have any outside contact or support beyond their husband. 


\section{Conclusion}

My analysis provides only a glimpse into the variety of experiences of mail-order brides that leave the Philippines to marry someone living in Canada. Because of the very sensitive nature of the topic, it has been impossible for me to find interviewees who would share their first-hand experiences of the "mail-order" relationship. This is understandable as sharing personal information can be very difficult for people, especially if it is traumatic information and based on experiences of domestic violence or verbal and emotional abuse. Because my research is not based on first-hand information, I realize that the knowledge I have acquired may not be comprehensive and represent the full picture. Nevertheless, the interviews with representatives from organizations serving the Filipino-Canadian communities have been insightful especially as they helped illuminate the diversity and complexity of experiences involved in "mail-order" relationships.

It is difficult to develop a conclusive perspective regarding the experiences of mail-order brides because of the significant differences between individual experiences. From my analysis, some patterns can be drawn although they do not necessarily apply to all mail-order brides. Many of the women becoming mail-order brides are educated, intelligent individuals who are seeking better economic opportunities through international migration. This is not to say that they do not love the man they are marrying. It does mean, however, that it would be extremely difficult for them to leave their marriages because it would mean not having money to send home to their families. Some may look at this as a case of the husband being used, but it is often a mutually exploitative relationship as the husbands often rely heavily on their wives, be it for cooking and cleaning around the home, caring for them in their illness or, as discussed, acting as the cultural broker for a new life in the Philippines. 
These marriages are not universally abusive. They do, however, involve extreme vulnerabilities because of the unequal balance of power where the wife may feel indebted to her husband or obligated to keep him happy so that there is no divorce and she can continue living in Canada. She does not do this only for herself, but because her family in the Philippines is likely relying on her to send remittances home.

Therefore, the issue of the vulnerability of mail-order brides cannot easily be corrected only by measures taken by the Canadian government. In part, the vulnerability of these women cannot be changed because it is the global conditions imposed by foreign debt, and national economies dependant on remittances, as well as extreme class inequalities that keep them vulnerable. As similar conditions are true of many other migrant workers from the Philippines, we must acknowledge that the system in place where remittances are encouraged by the government keeps emigrants, particularly the women, in incredibly vulnerable situations.

The debate that emerges when discussing mail-order brides, not just from the Philippines but from all countries, is the question of Canada's, as well as other Northern nations', responsibilities in the debt crisis faced by many Third World countries. There is a direct correlation between the Philippines' need for money as a country and the need for their citizens to move away from their families to be able to send a small amount of money home. These global inequalities help create vulnerable situations where women may choose to stay in abusive marriages because of the underlying economic motivation behind becoming a mail-order bride. It is ultimately through addressing global inequalities that we may hope to move towards elimination of conditions of vulnerability. 
In the short term, before structural inequalities can be addressed globally, Canada must do its part within the country to alleviate unnecessary pressures on these women. Regulatory action would be beneficial for helping to give women a realistic view of who they are marrying as well as helping the state keep fraudulent marriages to a minimum. As a country that claims to stand for basic freedoms, equal opportunity and women's rights, it is only fair that all immigrants that come into Canada are protected. As potential for vulnerability is far greater for mail-order brides, policies for prevention of abuse, violence and exploitation need to be extra vigilant for this group of immigrants. 


\section{References}

Abidi, C. B., \& Brigham, S. M. (2008). Crossing Global Borders: 'Mail Order Brides' in Atlantic Canada. Thinking Beyond Borders: Global Ideas, Global Values, Online Proceedings of the Canadian Association for the Study of Adult Education, $27^{\text {th }}$ National Conference 2008 at University of British Columbia, Vancouver. Retrieved from http:/www.oise.utoronto.ca/CASAE/cnf2008/Online Proceedings-2008/CAS2008Baillie\%20Abidi.pdf.

Alcuitas-Imperial, L., May, F., Sayo, C., Sioson, C. J., \& Vasquez, J. (2000, November). Canada: The New Frontier for Filipino Mail-Order Brides. Philippine Women Centre of BC. Retrieved from http://dsp-psd.pwgsc.gc.ca/Collection/SW21-62-2000E.pdf .

Belleau, M-C. (2003). Mail-Order Brides and Canadian Immigration Policy. Canadian Woman Studies, 22(3-4), 94-104.

Boyd, M., \& Vickers, M. (2000). 100 Years of Immigration in Canada. Canadian Social Trends, (Autumn), 2-13. Retrieved from http://www.statcan.gc.ca/kits-trousses/pdf/social/edu01b 0001d-eng.pdf

Carroll, N. (2008, January). Record High Remittances to the Philippines lead to Increased Competition among Philippine Banks. Federal Reserve Bank of San Francisco. Retrieved from http://www.frbsf.org/publications/banking/asiafocus/2008/ Asia_Focus_Jan 08.pdf

CIC. (2009) Sponsorship of a Spouse, Common-law Partner, Conjugal Partner or Dependent Child Living Outside Canada. Retrieved from http://www.cic.gc.ca/english/information/applications/guides/3900E2.asp

CIC. (2008). Fee Schedule for Citizenship and Immigration Services. Retrieved from hitp://www.cic.gc.ca/english/information/fees/fees.asp

Constable, N. (2003). Romance on a Global Stage: Pen Pals, Virtual Ethnography, and "MailOrder" Marriages. Berkeley: University of California Press.

Constable, N. (2006). Brides, Maids and Prostitutes: Reflections on the Study of 'Trafficked' Women. Journal of Multidisciplinary International Studies, 3(2 July), 1-25.

Creswell, J. W. (2009) Research Design: Qualitative, Quantitative, and Mixed Methods Approaches. Thousand Oaks, California: Sage Publications Inc.

D'Aoust, A-M. (2009, February 18). "Love Stops at the Border": Marriage, Citizenship, and the "Mail-Order Bride" Industry. Penn Program on Democracy, Constitutionalism and Citizenship Workshop at University of Pennsylvania. Retrieved from 
http://www.sas.upenn.edu/dcc/workshops/documents/DAoust_DCC_Grad_ Workshop_paper.pdf

del Rosario, T. C. (2008). Bridal Diaspora: Migration and Marriage among Filipino Women. In

Rajni Palriwala and Patricia Uberoi (Eds.), Marriage, Migration and Gender (pp. 78-97).

Thousand Oaks, California: Sage Publications Inc.

Glodava, M., \& Onizuka, R. (1994). Mail-Order Brides: Women for Sale. Fort Collins, Colorado: Alaken, Inc.

Kempadoo, K. (2005). Victims and Agents of Crime: The New Crusade against Trafficking. In J. Sudbury (Ed.), Global lockdown: Race, gender, and the prison-industrial complex (pp 35-55). New York: Routledge.

Langevin, L., \& Belleau, M-C. (2000, October). Trafficking Women in Canada: A Critical Analysis of the Legal Framework Governing Immigrant Live-In Caregivers and MailOrder Brides. Status of women Canada. Retrieved from http://www.childtrafficking.com/Docs/langevin_2000_trafficking_pdf

Lindee, K. M. (2007). Love, Honor, or Control: Domestic Violence, Trafficking, and the Question of how to Regulate the Mail-Order Bride Industry. Columbia Journal of Gender and Law, 16(2), 551-601.

Menjivar, C., \& Salcido, O. (2002). Immigrant Women and Domestic Violence Common Experience in Different Countries." Gender and Society, 6(16), 898-919.

Morgan, K. (2007). Here Comes the Mail-Order Bride: Three Methods of Regulation in the United States, the Philippines, and Russia. George Washington International Law Review, 29(2), 423-448.

Nadeau, K. (2008). The History of the Philippines. Westport, Connecticut: Greenwood Press.

Narayan, U. (1995). "Male-Order" Brides: Immigrant Women, Domestic Violence and Immigration Law. Hypatia 10(1), 104-119.

Pehar, J. (2003). e-Brides: the Mail-Order Bride Industry and the Internet. Canadian Woman Studies, 22(3-4), 171-175.

Perez, B. E. (2003). Woman Warrior Meets Mail-Order Bride: Finding an Asian American Voice the Women's Movement. Berkeley Women's Low Journal, 18, 211236.

Sims, R. A. (2008-2009). Comparison of Laws in the Philippines, The U.S.A., Taiwan, and Belarus to Regulate the Mail-Order Bride Industry. Akron Law Review, 42(2), 607-637. 
So, Christine. (2006). Asian Mail-Order Brides, the Threat of Global Capitalism, and the Rescue of the US Nation-State. Feminist Studies, 32(2), 395-417.

Tolentino, R. B. (1996). Bodies, Letters, Catalogues: Filipinas in Transnational Space. Social Text. 48(Autumn), 49-76.

Vergara, V. B M. (2000). Abusive Mail-Order Bride Marriage and the Thirteenth Amendment. Northwestern University Law Review, 94(4), 1547-1599.

Walton-Roberts, M. (2004). Rescaling Citizenship: Gendering Canadian Immigration Policy. Political Geographer, 23(3), 265-281. 